\title{
The dynamics of some physical and physico-chemical properties during composting of municipal solid wastes and biomass of energetic plants
}

\begin{abstract}
The aim of the research was to analyze the composting process with respect to changes in some physical and physicochemical properties of the organic part of municipal solid waste and willow and hay biomass mixture. The dynamics of changes in cation exchange capacity CEC values in relation to the base value of the initial materials of both tested composts were higher for municipal solid wastes compost (MSWC) compost than for willow biomass compost (WBC). The dynamics of pH changes were similar in the tested types of compost and were rather small during the process of composting, regardless of the type of organic residues and initial reaction. During composting process, the transformation of organic matter and mineral components slows down after reaching a stabilization phase.
\end{abstract}

Keywords: municipal solid waste compost, cation exchange capacity, compost maturity

\section{INTRODUCTION}

Composting is a part of the oxidative processes of biological and biochemical transformations that occur under strictly defined temperature, humidity and $\mathrm{pH}$ conditions as well as $\mathrm{C} / \mathrm{N}$ ratio. These factors influences the creation of suitable conditions in the composted material for microorganisms carrying out a cycle of transformation processes (Beffa et al. 1996, Ishii et al. 2000, Tiquia 2002, Horiuchi et al. 2003). The most important aspect in the production of compost is to ensure the proper course of organic matter transformation process so that the product obtained does not pose a threat when it is introduced into the soils and brings tangible benefits in the form of a positive impact on plant growth and development (Zhao et al. 2016, Chen et al. 2018).

The knowledge and understanding of the transformation of organic matter, which takes place in the composting process, as well as a proper assessment of the stability and maturity of compost, are necessary for the effective use of composts. The direction of organic matter transformation during the process depends on the type of composted material.

Composting is a dynamic processes during which many biochemical changes occur. As a consequence, also the physical properties of compost materials change (Mohee and Mudhoo 2005; Chen and Rosen 2014). The physical properties of the waste processed play an important role at every stage of the composting process as well as during the use of the final product (Haug 1993, Bekier et al. 2014). During the decomposition of organic matter, heat is released and the temperature rises, thus accelerating the biodegradation reaction. Knowledge of the physical properties of substrates and mixtures and their relations occurring during the composting process allows for effective process planning and execution as well as the selection of appropriate composting methods and technologies (Haug 1993, Agnew and Leonard 2003).

The aim of the research was to analyze the composting process with respect to changes in some physical and physicochemical properties of the organic part of municipal solid waste and willow and hay mixture biomass.

\section{MATERIALS AND METHODS} from:

The objects of the research were composts produced

1. the organic part of municipal solid waste (MSWC) from the Katowice agglomeration and

2. mixtures of hay and energy willow biomass (WBC).

The initial material of variant 2 was obtained according DANO technology (Rosik-Dulewska 2002). In both variants, the temperature and humidity measurements of composted piles were carried out on a daily basis at regular intervals. If necessary, irrigation and material mixing was carried out to maintain optimal 
water and air conditions. For laboratory tests, mixed samples were collected in different phases of compost maturity, which represented the initial material of both composts and after 1, 37, 54, 71, 130 and 167 days of composting. The times were chosen on the base of the temperature changes. On the basis of the collected material, the moisture was determined by weight-drying method, the $\mathrm{pH}$ of the water extract (in the ratio 1:10), potentiometric method, the cation exchange capacity (CEC) by the Harada and Inoko method (1980).

The results were statistically analyzed using Statistica 13. Correlation coefficients between individual parameters were calculated. Indexes of dynamics in the tested parameters were calculated, using the formula: $\mathrm{i}=\mathrm{y}_{1} / \mathrm{y}_{0}$

Where: $y_{1}$ means value of the parameter in the analyzed period, $\mathrm{y}_{0}$ means base value of the initial materials.

\section{RESULTS AND DISCUSSION}

One of the important factors in the correct course of composting is the temperature both outside and inside of the composting pile, which is one of the most important physical criteria for assessing compost maturity and, at the same time, is a measurable indicator of biotransformation processes intensity during the composting process (Tiquia et al. 1996, Drozd et al. 2004). In the compost produced from biomass of willow and hay mixture, the thermophilic phase was reached after 13 days of composting and lasted for 14 days (Fig. 1). In the compost from municipal waste, the thermophilic phase was reached after only 5 days and lasted much longer, for as much as 40 days. Experiments carried out so far have allowed us to conclude that there is a strict negative correlation between temperature and oxygen concentration (Tiquia 2002, Ryckeboer et al. 2003). The authors cited above have demonstrated that if the temperature of the composted mass was in the range of $65-70^{\circ} \mathrm{C}$, the transformation processes proceeded similarly to anaerobic conditions, regardless of the number and size of air pores in the pile.

Composted material moisture is one of the most important parameters for biological activity in the pile (Luangwilai et al. 2011, Ozimek 2012). Water content affects the structural and thermal compost properties as well as the rate of biodegradation (Stentiford 1996). In the presented experiment, the moisture in both compost piles ranged between $35.7-71 \%$ (Table 1), which ties in well with the statement that majority of composting process operates within these bands (Richard et al. 2002).

Studies carried out by Chen et al. (1996) and Drozd et al. (2004) indicate there are $\mathrm{pH}$ changes during the composting process. The value of this parameter in the final phases is close or slightly higher than the initial value (Gondek et al. 2014), whereas during maturation, small changes in $\mathrm{pH}$ are usually observed. These changes result from different intensities of biochemical processes occurring during composting, which depend mainly on maturing compost temperature, oxygen content and humidity.

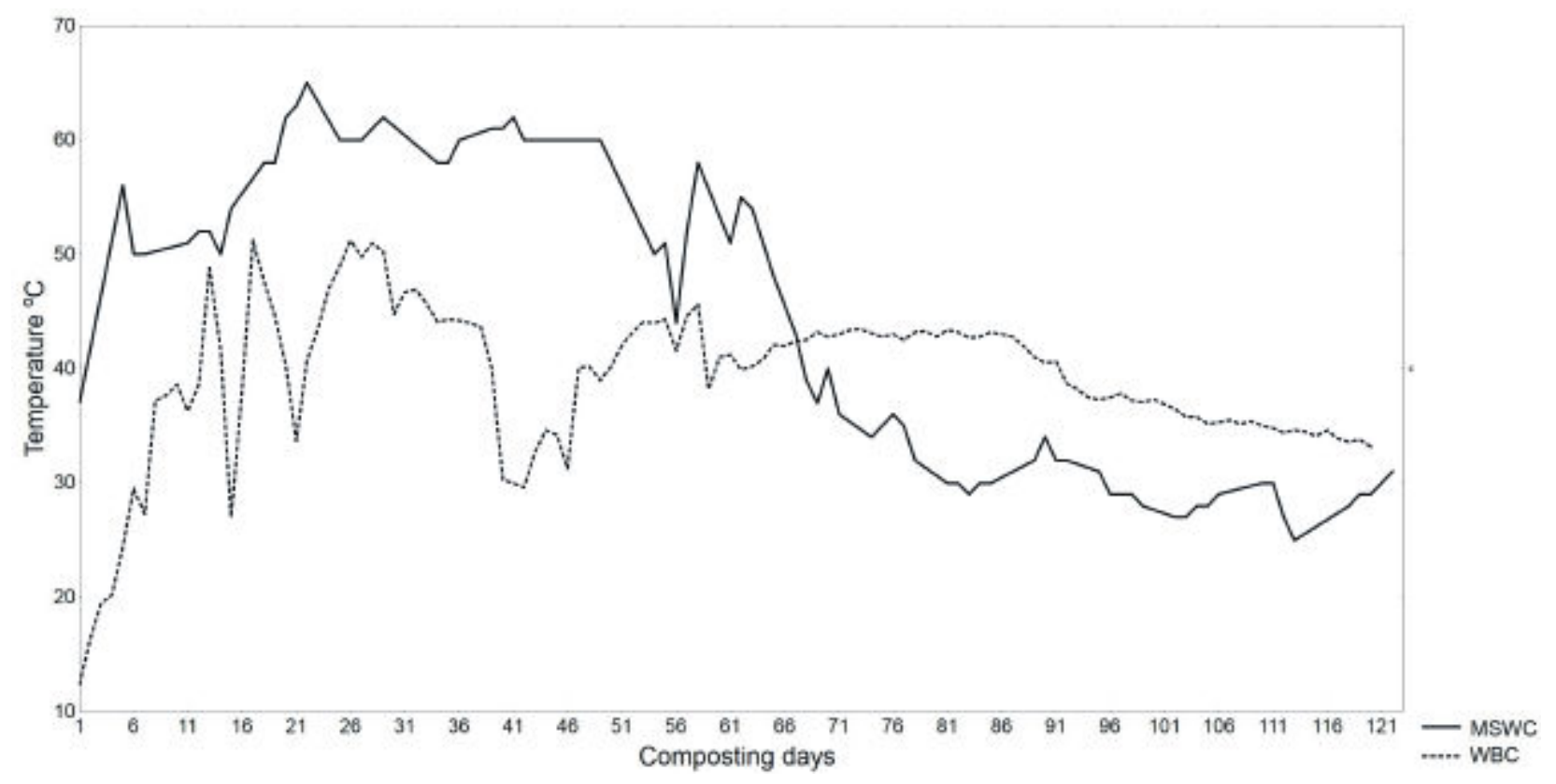

FIGURE 1. Temperature changes during composting of municipal solid waste compost (MSWC) and willow biomass compost (WBC) 
TABLE 1. The moisture, $\mathrm{pH}$ and CEC during composting of municipal solid waste compost (MSWC) and willow biomass compost (WBC)

\begin{tabular}{|c|c|c|c|c|c|c|}
\hline \multirow{2}{*}{$\begin{array}{l}\text { Compost } \\
\text { type }\end{array}$} & \multicolumn{6}{|c|}{ Composting days } \\
\hline & $\overline{1}$ & 37 & 54 & 71 & 130 & 167 \\
\hline & \multicolumn{6}{|c|}{ Moisture [\%] } \\
\hline WBC & 35.7 & 38.9 & 46.4 & 61.3 & 71.0 & 68.4 \\
\hline \multirow[t]{2}{*}{ MSWC } & 46.8 & 46.9 & 52.4 & 48.3 & 45.4 & 45.2 \\
\hline & \multicolumn{6}{|c|}{$\mathrm{pH}\left[\mathrm{H}_{2} \mathrm{O}\right]$} \\
\hline WBC & 5.3 & 5.4 & 5.5 & 5.6 & 5.8 & 6.0 \\
\hline \multirow[t]{2}{*}{ MSWC } & 6.9 & 7.5 & 7.9 & 7.7 & 8.3 & 7.7 \\
\hline & \multicolumn{6}{|c|}{ CEC [ $\mathrm{cmol}^{-\mathrm{kg}^{-1}}$} \\
\hline WBC & 18.65 & 13.15 & 20.35 & 27.55 & 24.1 & 25.9 \\
\hline MSWC & 37.7 & 54.7 & 62.2 & 59.7 & 67.9 & 73.2 \\
\hline
\end{tabular}

The results obtained showed there was a difference in $\mathrm{pH}$ of the aqueous extracts between the tested composts. WBC was characterized by an acid reaction (pH 5.3-6.0), while the MSWC $\mathrm{pH}$ exceeded 7.0 (Table 1). These results are consistent with numerous authors' studies (De Haan 1981, Maćkowiak and Orzechowska 1993), who also showed that compost produced from municipal waste is generally characterized by neutral or alkaline reaction. The increase of $\mathrm{pH}$ during composting indicates the course of ammonification processes, especially in the thermophilic phase of composting, when especially in MSWC there is a marked change in $\mathrm{pH}$ in the alkaline direction (from 6.9 to 7.9). After the thermophilic phase, both composts still show a small increase in $\mathrm{pH}$ (Table 1).

The cation exchange capacity and degree of organic residue decomposition are significantly correlated according many authors (Harada and Inoko 1980; Martinho et al. 2015). Therefore this parameter seems to be a good index of compost maturity and indicates a compost's ability to retain nutrients. CEC usually increases during composting but many authors suggest different values for CEC in matured compost, depending on type of organic residues. IglesiasJimenez and Perez-Garcia (1992) reported that municipal waste compost reached maturity when value of CEC was over $60 \mathrm{cmol} \cdot \mathrm{kg}^{-1}$. Bernal et al. (1996) found this value for compost from sweet sorghum bagasse with sewage sludge only after 21 days of composting, which definitely could not be the end of the process. Transformation of organic matter during composting process, in general, leads to the formation of humic substances with higher amounts of functional groups affecting CEC (Kumada 1956, Bernal et al. 1996, Senesi and Brunetti 1996), so this parameter rather reflects the degree of humification processes advance. The difference of CEC
TABLE 2. Single based dynamic indexes for municipal solid waste compost (MSWC) and willow biomass compost (WBC)

\begin{tabular}{lllll}
\hline \multirow{2}{*}{$\begin{array}{l}\text { Composting } \\
\text { days }\end{array}$} & WBC & \multicolumn{3}{c}{ MSWC } \\
\cline { 2 - 5 } & $\mathrm{pH}$ & $\mathrm{CEC}$ & $\mathrm{pH}$ & $\mathrm{CEC}$ \\
\hline 1 & 1.00 & 1.00 & 1.00 & 1.00 \\
\hline 37 & 1.02 & 0.71 & 1.08 & 1.45 \\
\hline 54 & 1.04 & 1.09 & 1.15 & 1.65 \\
\hline 71 & 1.06 & 1.48 & 1.12 & 1.58 \\
\hline 130 & 1.09 & 1.29 & 1.21 & 1.80 \\
\hline 167 & 1.12 & 1.39 & 1.11 & 1.94 \\
\hline
\end{tabular}

values observed between tested composts at various stages of maturation is related to the type of organic residues (Table 1). The obtained results that were much higher for municipal waste in comparison to those from biomass of energetic willow, confirm that this parameter cannot be treated as the only and objective compost maturity criterion.

Interesting results have been obtained by calculating the dynamics of changes in CEC values in relation to the base value of the initial materials of both tested composts (Table 2). The dynamics (an increase in both cases) were higher for MSWC than for compost from willow biomass although in both experiments a temporary decrease of dynamic intensity was observed after 54 days in MSW compost and after 71 days in willow biomass compost. These results are in agreement with decrease of CEC that has been observed in the same stages of compost maturity. The dynamics of $\mathrm{pH}$ changes were similar in the tested types of compost. Linear increase of $\mathrm{pH}$ dynamics were observed for energy willow compost while for MSWC there was a small decrease in intensity after 54 days of composting. Both composts from willow and municipal wastes showed similar values for single based dynamics indexes -1.12 and 1.11 respectively at the end of composting process (Table 2). It can be concluded that transformation of organic matter and mineral components during composting process expressively slowed down after reaching a certain stage of maturity. This stage is related to stabilization phase according to the temperature changes.

Table 3 presents significant correlation coefficients of the relationships forming during the composting process of both types of biomasses. Particularly noteworthy is the relationship between individual parameters and number of composting days. On the basis of the obtained results, a significant increase of $\mathrm{pH}$ can be observed with the composting time of both tested composts. Composting time significantly influenced an increase of CEC in compost produced from municipal solid waste. 
TABLE 3. Significant correlation coefficients between some of the physical and physico-chemical parameters in the municipal solid waste compost (MSWC) and willow biomass composts (WBC)

\begin{tabular}{lllllllll}
\hline Variable & \multicolumn{1}{l}{ WBC } & \multicolumn{7}{l}{ MSWC } \\
\cline { 2 - 10 } & $\begin{array}{l}\text { Composting } \\
\text { days }\end{array}$ & Moisture [\%] & $\mathrm{pH}$ & $\mathrm{CEC}$ & $\begin{array}{l}\text { Composting } \\
\text { days }\end{array}$ & Moisture [\%] & $\mathrm{pH}$ & CEC \\
\hline Composting days & $\mathrm{X}$ & 0.92 & 0.99 & & $\mathrm{X}$ & & 0.66 & 0.91 \\
\hline Moisture [\%] & 0.92 & $\mathrm{X}$ & 0.93 & 0.83 & & $\mathrm{X}$ & $\mathrm{X}$ & 0.81 \\
\hline $\mathrm{pH}$ & 0.99 & 0.93 & $\mathrm{X}$ & & & & 0.81 & $\mathrm{X}$ \\
\hline $\mathrm{CEC}$ & & 0.83 & & $\mathrm{X}$ & 0.91 & & 0.81 \\
\hline
\end{tabular}

significant for $\mathrm{p}=0.05, \mathrm{n}=24$.

\section{CONCLUSIONS}

1. Composts produced from more differential organic residues, like municipal solid wastes, indicate higher dynamics of changes some physico-chemical parameters like CEC during the process of maturation in comparison to those produced from biomass. Single based dynamics index for CEC can be used in determining the quality of matured compost.

2. CEC values cannot be used as the only and objective criterion of compost maturity.

3. The $\mathrm{pH}$ dynamics is rather small during the process of composting regardless of the type of organic residues.

4. Transformation of organic matter and mineral components during composting process slows down after reaching stabilization phase.

\section{REFERENCES}

Agnew J.M., Leonard J.J., 2003. The physical properties of compost. Compost Science and Utilization 11(3): 238-264.

Beffa T., Blanc M., Marilley L., Frischer J.L., Lyon F., Arago M., 1996. Taxonomic and Metabolic Microbial Diversity During Composting. [In:] The Science of Composting (red.) Bertoldi M., Sequi P., Lemmes B., Papi T. Blackie Academic \& Proffesional, London, Glasgow, Wienheim, New York, Tokyo, Melbourne, Madras: 149-161.

Bekier J., Drozd J., Jamroz E., Jarosz B., Kocowicz A., Walenczak K., Weber J., 2014. Changes in selected hydrophobic components during composting of municipal solid wastes. Journal of Soils and Sediments 14(2): 305-311.

Bernal M.P., Navarro A.F., Roig A., Cegarra J., Garcia D., 1996. Carbon and nitrogen transformation during composting of sweet sorghum bagasse. Biology and Fertility of Soils 22: 141-148.

Chen Y., Chefetz B., Harada Y., 1996. Formation and Properties of Humic Substance Origination from Compost. [In:] The Science of Composting. (red.) de Bertoldi M., Sequi P., Lemmes B., Papi T. Blackie Academic \& Proffesional, London, Glasgow, Wienheim, New York, Tokyo, Melbourne, Madras: 382-393.
Chen Y., Rosen V., 2014. The influence of compost addition on heavy metal distribution between operationally defined geochemical fractions and on metal accumulation in plant. Journal of Soils and Sediments 14: 713-720.

Chen H., Dou J., Xu H., 2018. Remediation of Cr(VI)-contaminated soil with co-composting of three different biomass solid wastes. Journal of Soils and Sediments 18(3): 897-905.

De Haan S., 1981. Results of municipal wastes compost research over more than fifty years at the Institute for Soil Fertility at Haren/Groningen. The Journal of Agricultural Science 29: 49-61.

Drozd J., Licznar M., 2004. Zmiany właściwości fizycznych i fizykochemicznych podczas kompostowania odpadów komunalnych w różnych warunkach. [In:] Komposty z odpadów komunalnych - produkcja wykorzystanie i ich wpływ na środowisko. Drozd J. (red.), Polskie Towarzystwo Substancji Humusowych, Wrocław: 120-129.

Gondek K., Kopec M., Mierzwa M., Tabak M., Chmiel M., 2014. Chemical and biological properties of composts produced from organic waste. Journal of Elementology 19(2): 377-390.

Harada Y., Inoko A., 1980. The measurement of the cation-exchange capacity of composts for the estimation of the degree of maturity, Soil Science and Plant Nutrition 26(1): 127-134.

Haug R., 1993. Practical Handbook of Compost Engineering, Lewis Publishers, Boca Raton: 752 pp.

Horiuchi J.I., Ebie K., Tada K., Kobayashi M., Kanno T., 2003. Simplified method of estimation of microbal activity in compost by ATP analysis. Bioresources Technology 86: 95-98.

Iglesias-Jimenez E., Perez-Garcia V., 1992. Determination of maturity indices for city refuse composts. Agriculture, Ecosystems and Environment 38: 331-343.

Ishii K., Fukui M., Takii S., 2000. Microbial succesion during a composting process as evaluated by denaturing gradient gel electrophoresis analysis. Journal of Applied Microbiology 89: 768-777.

Kumada K., 1956. Several properties of humic acids, Soil Plant Food 2: 44-48.

Luangwilai T., Sidhu H.S., Nelson M.I. \& Chen X., 2011. Modelling the effects of moisture content in compost piles. Australian Chemical Engineering Conference in Australia, New South Wales: 18-21.

Maćkowiak C., Orzechowska K., 1993. Produkcja, skład chemiczny oraz wartość nawozowa kompostu produkowanego z odpadów miejskich w ciągu technologicznym „DANO”. Zeszyty Problemowe Postępów Nauk Rolniczych 437: 369-374. 
Mohee R., Mudhoo A., 2005. Analysis of the physical properties of an in-vessel composting matrix, Powder Technology 155: 92-99.

Martinho J., Campos B., Bras I., Silva E., 2015. The role of compost properties in sorption of heavy metals. Environmental Protection Engineering 41(2): 57-66.

Ozimek A., Kopeć M., 2012. Ocena aktywności biologicznej biomasy na różnych etapach procesu kompostowania przy użyciu systemu pomiarowego Oxitop Control. Acta Agrophysica 19(2): 379-390.

Ryckeboer J., Mergaert J.,Coosemans J., Deprins K., Swings J., 2003. Microbiological aspects of biowaste during composting in a monitored compost bin. Journal of Applied Microbiology 94: 127-137.

Richard T.L., Hamelers H.V.M. (Bert), Veeken A., Silva T., 2002. Moisture Relationships in Composting Processes, Compost Science \& Utilization 10(4): 286-302.

Rosik-Dulewska C., 2002. Podstawy gospodarki odpadami. PWN, Warszawa (in Polish).

Senesi N., Brunetti G., 1996., Chemical and physico-chemical parameters for quality evaluation of humic substances produced during composting. [In:] The Science of Composting. [Red.] de Bertoldi M., Sequi P., Lemmes B., Papi T. Blackie Academic \& Proffesional, London, Glasgow, Wienheim, New York, Tokyo, Melbourne, Madras: 195-212.
Stentiford E.I., 1996. Composting Control: Principles and Practice. [In:] The Science of Composting, [Red.] Bertoldi M., Sequi P., Lemmes B., Papi T. Blackie Academic \& Professional, London, Glasgow, Weinheim, New York, Tokyo, Melbourne, Madras: 49-59.

Tiquia M., Tam N.F.Y, Hodgkiss I.J., 1996. Effects of Moisture Content on the Composition of Pig - Manure Sawdust Litter Disposed From the Pig-on Littre System. [In:] The Science of Composting, [Red. ] Bertoldi M., Sequi P, Lemmes B., Papi T. Blackie Academic \& Professional, London, Glasgow, Weinheim, New York, Tokyo, Melbourne, Madras: 13611364.

Tiquia S.M., 2002. Evolution of extracellular enzyme activities during manure composting. Journal of Applied Microbiology 92: 764-775.

Zhao X., He X., Xi B., Gao R, Tan W., Zhang X., Li D., 2016. The evolution of water extractable organic matter and its association with microbial community dynamics during municipal solid waste composting. Waste Management 56: 79-87.

Received: April 12, 2018

Accepted: July 18, 2018

Associated editor: A. Lachacz

\title{
Dynamika wybranych właściwości fizycznych i fizykochemicznych podczas kompostowania stałych odpadów komunalnych i biomasy roślin energetycznych
}

\begin{abstract}
Streszczenie: Celem badań była analiza procesu kompostowania pod kątem dynamiki zmian wybranych właściwości fizycznych i fizykochemicznych organicznej części komunalnych odpadów stałych oraz mieszaniny biomasy wierzby i siana. Pojemność wymiany kationów kompostów produkowanych z organicznej części odpadów miejskich podlegała większej dynamice zmian podczas procesu dojrzewania, w porównaniu do kompostów z mieszaniny biomasy roślin energetycznych. Dynamika zmian odczynu podczas procesu kompostowania była niewielka i nie zależała od rodzaju przetwarzanego materiału organicznego. Na podstawie uzyskanych wyników stwierdzono, że analiza dynamiki zmian pojemności wymiany kationów wskazuje na możliwość wykorzystania tego indeksu przy ocenie stopnia dojrzałości kompostów, natomiast wartości tego parametru nie mogą stanowić wyłącznej podstawy do oceny jakości produkowanych kompostów. Podczas procesu kompostowania, po osiagnięciu fazy stabilizacji, odnotowano wyraźne spowolnienie procesu przemian materii organicznej i składników mineralnych.
\end{abstract}

Stowa kluczowe: kompost, stałe odpady komunalne, pojemność wymiany kationów, indeksy dojrzałości kompostu 